\title{
Magnesium Status in Idiopathic Calcium Urolithiasis - An Orientational Study in Younger Males ${ }^{1}$ )
}

\author{
Angelika Schmiedl and Paul O. Schwille \\ Mineral Metabolism and Endocrine Research Laboratory, Departments of Surgery and Urology, \\ University of Erlangen, Erlangen, Germany
}

Summary: With the aim of revealing a possible magnesium $(\mathrm{Mg})$ deficiency in the aetiology of idiopathic recurrent calcium urolithiasis we studied the $\mathrm{Mg}$ content of red blood cells, serum total, protein-bound, ionised and complexed fractions of $\mathrm{Mg}$, and urinary $\mathrm{Mg}$ after an overnight fast. The two study groups comprised 12 male recurrent calcium urolithiasis patients and 12 healthy male controls (mean age 31 and 29 years, respectively). In recurrent calcium urolithiasis, serum albumin and $\mathrm{Mg}$ of erythrocytes were significantly decreased, as was serum total and proteinbound $\mathrm{Mg}$, whereas serum ultrafiltrable, ionised and complexed $\mathrm{Mg}$ were statistically indistinguishable from values in controls. Urinary $\mathrm{Mg}$ (per unit creatinine) in recurrent calcium urolithiasis (mean 0.188 vs 0.209 in controls; $\mathrm{p}=0.386$ ) was not statistically different, whereas urinary total protein, glucose, and $\mathrm{pH}$ were significantly increased. The renal clearances of $\mathrm{Mg}$ and glucose were positively correlated $(\mathrm{r}=0.56 ; \mathrm{p}<0.01)$, with a steeper slope in recurrent calcium urolithiasis than controls. Further fractionation of serum and urinary $\mathrm{Mg}$ into ions and complexes in recurrent calcium urolithiasis subjects with identical creatinine clearance revealed no statistical difference between

1) $\mathrm{Mg}$ ions and complexes filtered by renal glomeruli;

2) $\mathrm{Mg}$ ions and complexes excreted in urine;

3) fractional $\mathrm{Mg}$ excretion.

Median urine supersaturation with respect to calcium oxalate was insignificantly lower (1.5 vs 2.2$)$, with respect to hydroxyapatite insignificantly higher ( $3.3 \mathrm{vs} 1.8)$, than in controls.

It is concluded that relatively young recurrent calcium urolithiasis patients exhibit a deficiency of $\mathrm{Mg}$ in erythrocytes and serum total $\mathrm{Mg}$, but no alteration of renal $\mathrm{Mg}$ handling. Thus, in recurrent calcium urolithiasis, a role of $\mathrm{Mg}$ deficiency in urine as a factor initiating stone formation may be ruled out, whereas a possible link between cellular $\mathrm{Mg}$ deficiency and the impairment of renal tubular functions involved in reabsorption of glucose and proteins, and in urine acidification, deserves further studies.

\section{Introduction}

Magnesium (Mg) is an important element in biological calcification processes, where it can play a dual role. In skeletal tissue, for example, it may be a promotor of the maturation of hydroxyapatite prior to deposition $(1,2)$, and it may also be an inhibitor of calcium phosphate crystallisation (3), its actual role being determined by the prevailing physico-chemical environment. On the other hand, in alkaline urine, excess $\mathrm{Mg}$ can promote the formation of Mg-ammonium-phosphate stones, while the crystallisation of calcium phosphates and calcium oxalates is inhibited by $\mathrm{Mg}$ in acidic urine (4-6). With regard to calcium oxalate, the mechanisms contributing

1) Supported by the Erlangen University Hospital research funds, and the Division of Research and Development, Madaus, Cologne; Germany to inhibition are believed to be a Mg-induced decrease in both biosynthesis and urinary excretion of oxalate (for details see 1 .c. $(7,8)$ ), but also complexation of urinary oxalate, and growth retardation of preformed calcium oxalate crystals $(9,10)$. In view of this situation, there is a clear need to determine whether or not patients with renal calcium stones have a $\mathrm{Mg}$ deficiency, especially in the urine. In so-called idiopathic recurrent calcium urolithiasis, comprising patients with calcium oxalate and mixed (mostly calcium oxalate and calcium phosphate) stones, earlier investigations in this area provided conflicting results $(11-14)$. However, some of these are probably due to the fact that patients and controls in those studies were not, or only poorly, matched with respect to sex, age, body mass index, or lean body mass, the latter two as measures of obesity. Overweight is a frequent feature of males with recurrent calcium urolithiasis (15), and since these variables have a significant 
association with $\mathrm{Mg}$ deficiency (16), studies on $\mathrm{Mg}$ that neglect this may be seriously biased. Furthermore, because urinary $\mathrm{Mg}$ and the renal handling of $\mathrm{Mg}$ depend on the body stores of $\mathrm{Mg}$, extracellular $\mathrm{Mg}$ included, it is essential that cellular content, serum fractions, and urinary content of $\mathrm{Mg}$ are investigated together. Since urinary $\mathrm{Mg}$ acts predominantly in its ionised form as an inhibitor of calcium oxalate crystal growth, renal handling of serum $\mathrm{Mg}$, separately for ionised and complexed $\mathrm{Mg}$ filtered by glomeruli, is of major interest; similarly, also in urine, total Mg should be considered separately as free ions and complexes. Such work has not been carried out up to now in renal calcium stone research.

The present work was conceived as a pilot study with the aim of identifying a possible $\mathrm{Mg}$ deficiency in recurrent calcium urolithiasis by means of assessing the fasting $\mathrm{Mg}$ content of red blood cells, the biological fractions of $\mathrm{Mg}$ in serum, and the concomitant urinary excretion of $\mathrm{Mg}$.

\section{Materials and Methods}

\section{Study participants and procedures}

Informed consent was obtained from all participants. Twelve male recurrent calcium urolithiasis patients (mean age 31 years, range 19-43) and twelve male healthy subjects (mean age 29 years, range 23-43) were studied, the latter serving as controls. The study participants were ambulatory, and all were on their usual home diet until 6:00 p.m. on the day before they entered the hospital.

In recurrent calcium urolithiasis, the absence of disorders characterised by concomitant stone formation, such as primary hyperparathyroidism, renal tubular acidosis, oxalosis, enteric hyperoxaluria, or gout was verified. Also, subjects with hypertension, diabetes, hyperthyroidism, or urinary tract infection were excluded. The duration of stone disease ranged from 2 months to 29 years. Stone analysis revealed calcium oxalate in nine, mixed stones (calcium oxalate plus calcium phosphate) in two, and some indeterminate calcium salt in one. At the time of laboratory examination (see below) stones were present in 7 of the 12 recurrent calcium urolithiasis patients.

The order of magnitude of several anthropometric and metabolic quantities was similar, and the mean values were as following:

body mass index was 23.9 [recurrent calcium urolithiasis] and 22.7 [controls] $\mathrm{kg} /(\mathrm{cm})^{2}$;

serum creatinine 80.3 [recurrent calcium urolithiasis] and 85.5 [controls] $\mu \mathrm{mol} / \mathrm{l}$;

serum glucose 4.76 [recurrent calcium urolithiasis] and 4.79 [controls] $\mathrm{mmol} / \mathrm{l}$;

plasma citrate 0.11 [recurrent calcium urolithiasis] and 0.11 [controls] mmol/l;

the median urinary sodium was 7.83 [recurrent calcium urolithiasis] and 7.70 [controls] mol/mol urinary creatinine.

The latter value makes it unlikely that excess salt had been taken by recurrent calcium urolithiasis patients with the daily home diet. In both patients and controls, serum potassium and blood gases were within normal limits, the creatinine clearance exceeded $1 \mathrm{ml} /$ $\min \cdot \mathrm{kg}$ body weight, the fasting urinary calcium/creatinine ratio was normal $(<0.34 \mathrm{mmol} / \mathrm{mmol}$ creatinine), except for three recurrent calcium urolithiasis patients who showed fasting hypercal- ciuria but whose other quantities were within the range of the normocalciuric stone formers. None of the participants was hyperoxaluric (upper limit of normal in this laboratory $0.39 \mathrm{mmol}$ per day), and none was on long-term anti-stone medication or using any daily $\mathrm{Mg}$ supplementation via food or drinks.

On the day of the examination the following steps [part of a standardised programme developed to investigate disturbances of mineral metabolism (17) and yielding reproducible results upon repeat application (unpublished data)] were taken in the clinical laboratory after an novernight $12-14 \mathrm{~h}$ fasting period: 7:30 a. m. bladder voiding, stimulation of mild diuresis (approx! $1 \mathrm{ml}$ urine per minute) by drinking demineralised water, followed by collection of a timed $(2 \mathrm{~h})$ fasting urine, puncture of a forearm vein and aspiration of blood without statis.

Physical exercise during the laboratory procedure was kept to a minimum in all participants to rule out unspecifically stimulated proteinuria (18).

\section{Analyses}

Routine methods were employed for blood gases (Blood Gas Analyser, Instrumentation Laboratory, Milan; Italy), urinary $\mathrm{pH}(\mathrm{pH}$ meter 691, Metrohm, Filderstadt, Germany), and creatinine, sodium, potassium (Autoanalyser 747, Hitachi, Japan), calcium (by complexometry, using Calcium analyser 940, Corning, Halstead; UK) and phosphorus (as inorganic phosphate, Kit No. 3331, Merck, Darmstadt; Germany) in serum and urine. Oxalate in urine was measured by ion chromatography (19). Additional variables investigated were haematocrit, total protein [in serum by refractometry, in urine by colorimetry (reagents from Bio-Rad Laboratories, Munich; Germany)], albumin [in serum by colorimetry, in urine by nephelometry (using the monoclonal antibody, OSAL 14, Behring, Marburg; Germany)]. Atomic absorption spectrophotometry [FL 6, Zeiss, Oberkochen; Germany (inter-assay coefficient of variation $=0.6 \%$, based on $n=29$ control serum samples)] was used to determine undiluted serum $\mathrm{Mg}, \mathrm{Mg}$ in ultrafiltrate of anaerobically handled serum samples [pressure filtration (nitrogen, 3 bars) through a $M_{\mathrm{r}} 10000$ cellulose triacetate membrane; Sartorius, Göttingen, Germany], and $\mathrm{Mg}$ in heparinised plasma and whole blood, containing $17-20 \cdot 10^{3}$ IU Na-heparin per litre sample. Ionised $\mathrm{Mg}$ in heparinised whole blood was determined using a sensitive electrode (CRT 8, Nova Biochemical, Rödermark; Germany), as described by Altura et al. (20). Serum human intact parathyroid hormone was measured using a commercial kit (Nichols, Bad Nauheim; Germany). Serum and urinary citrate (21), and serum and urinary glucose (Glucose Analyser 2, Beckman, Fullerton; USA) were determined enzymatically.

\section{Calculations and statistics}

The concentration of $\mathrm{Mg}$ in erythrocytes (expressed in $\mathrm{mmol} / \mathrm{l}$ ) was calculated as

$\mathrm{P}+[100(\mathrm{~W}-\mathrm{P}): \mathrm{H}]$,

where $\mathrm{P}$ is plasma $\mathrm{Mg}$,

$\mathrm{W}$ is $\mathrm{Mg}$ in haemolysed whole blood, and

$\mathrm{H}$ is the haematocrit (22).

The serum protein-bound and the complexed $\mathrm{Mg}$ fractions were taken as the difference between the concentration of the serum total and ultrafilterable fraction, and the serum ultrafiltrable and ionised fraction, respectively. The renal filtered load of total $\mathrm{Mg}, \mathrm{Mg}$ ions, and $\mathrm{Mg}$ complexes was taken as the product of the respective concentration in the ultrafiltrate and the creatinine clearance. Equil-2 software (23) was used for the calculation of urinary ionised and complexed $\mathrm{Mg}$, and the relative supersaturation products of calcium oxalate, brushite, and hydroxyapatite in urine. To prevent errors in bladder voiding, substances in urine were factorised for urinary creatinine. The results in urine are expressed as arithmetic means (range), in blood as arithmetic means (SEM), if not otherwise indicated. Differences between groups were tested for significance $(p<0.05)$ by the $t-$ or U-test, as appropriate. For several variables Spearman's correlation coefficient was assessed. 
Tab. 1 Baseline clinical chemistry data of patients with recurrent calcium urolithiasis and controls (healthy non-stone-forming indi- viduals). Mean values (SEM, or range of valucs). S: serum; P: plasma; U: urine. *: $\mathrm{p}<0.05$ vs Controls.

\begin{tabular}{|c|c|c|c|c|c|}
\hline \multirow[b]{2}{*}{ S-Total protein; $g / 1$} & \multicolumn{2}{|c|}{$\begin{array}{l}\text { Recurrent calcium } \\
\text { urolithiasis } \\
n=12\end{array}$} & \multicolumn{2}{|l|}{$\begin{array}{l}\text { Controls } \\
n=12\end{array}$} & \multirow{2}{*}{$\frac{p \text {-value }}{0.740}$} \\
\hline & 70.3 & $(3.9)$ & 69.8 & $(3.6)$ & \\
\hline S-Albumin; $\mathrm{g} / \mathrm{l}$ & $47.5^{*}$ & $(10)$ & 49.7 & $(1.8)$ & 0.001 \\
\hline S-Total calcium; mmol/l & 2.30 & $(0.018)$ & 2.29 & $(0.020)$ & 0.808 \\
\hline S-Phosphate; $\mathrm{mmol} / \mathrm{I}$ & 1.03 & $(0.05)$ & 1.10 & $(0.06)$ & 0.362 \\
\hline P-Parathyrin; ng/l & 26.7 & $(9.79)$ & 25.6 & $(16.6)$ & 0.157 \\
\hline U-pH & $6.02 *$ & $(4.8-6.9)$ & 5.43 & $(4.8-6.6)$ & 0.025 \\
\hline U-Creatinine clcarance; $\mathrm{ml} / \mathrm{min}$ & 125 & $(91-188)$ & 106 & $(66-167)$ & 0.107 \\
\hline U-Protein; $\mathrm{g} / \mathrm{mol}$ creatinine & $3.76^{*}$ & $(1.0-21.3)$ & 2.11 & $(0.7-3.7)$ & 0.026 \\
\hline U-Albumin; $\mu \mathrm{mol} / \mathrm{mol}$ creatinine & 7.65 & $(0-15.0)$ & 4.03 & $(0-11.9)$ & 0.207 \\
\hline U-Glucose; $\mathrm{mol} / \mathrm{mol}$ creatinine & $0.049 *$ & $(0.02-0.13)$ & 0.020 & $(0.01-0.04)$ & 0.005 \\
\hline U-Calcium; mol/mol crcatinine & 0.309 & $(0.06-0.95)$ & 0.157 & $(0.02-0.38)$ & 0.214 \\
\hline U-Magnesium; mol/mol creatinine & 0.188 & $(0.08-0.45)$ & 0.209 & $(0.14-0.3)$ & 0.386 \\
\hline U-Potassium: $\mathrm{mol} / \mathrm{mol}$ creatinine & 5.73 & $(2.3-12.6)$ & 4.56 & $(2.1-11.02)$ & 0.341 \\
\hline U-Citrate; $\mathrm{mol} / \mathrm{mol}$ creatinine & 0.144 & $(0.05-0.35)$ & 0.154 & $(0.04-0.30)$ & 0.863 \\
\hline U-Phosphate; $\mathrm{mol} / \mathrm{mol}$ creatinine & 0.97 & $(0.41-2.42)$ & 1.39 & $(0.58-2.2)$ & 0.069 \\
\hline U-Oxalate; $\mathrm{mol} / \mathrm{mol}$ creatinine & 0.012 & $(0.01-0.02)$ & 0.013 & $(0.01-0.02)$ & 0.707 \\
\hline U-Glucose clearance; $\mathrm{ml} / \mathrm{min}$ & $0.10^{*}$ & $(0.05-0.22)$ & 0.04 & $(0.02-0.06)$ & 0.001 \\
\hline U-Magnesium clearance; $\mathrm{ml} / \mathrm{min}$ & 3.48 & $(1.28-5.65)$ & 3.00 & $(1.60-4.68)$ & 0.442 \\
\hline
\end{tabular}

\section{Results}

\section{General data}

The baseline clinical chemistry data in recurrent calcium urolithiasis patients and controls, matched for sex, age, body mass index, renal function (see Material and Methods), are shown in table 1. Except for serum albumin, the mean value of which in recurrent calcium urolithi-

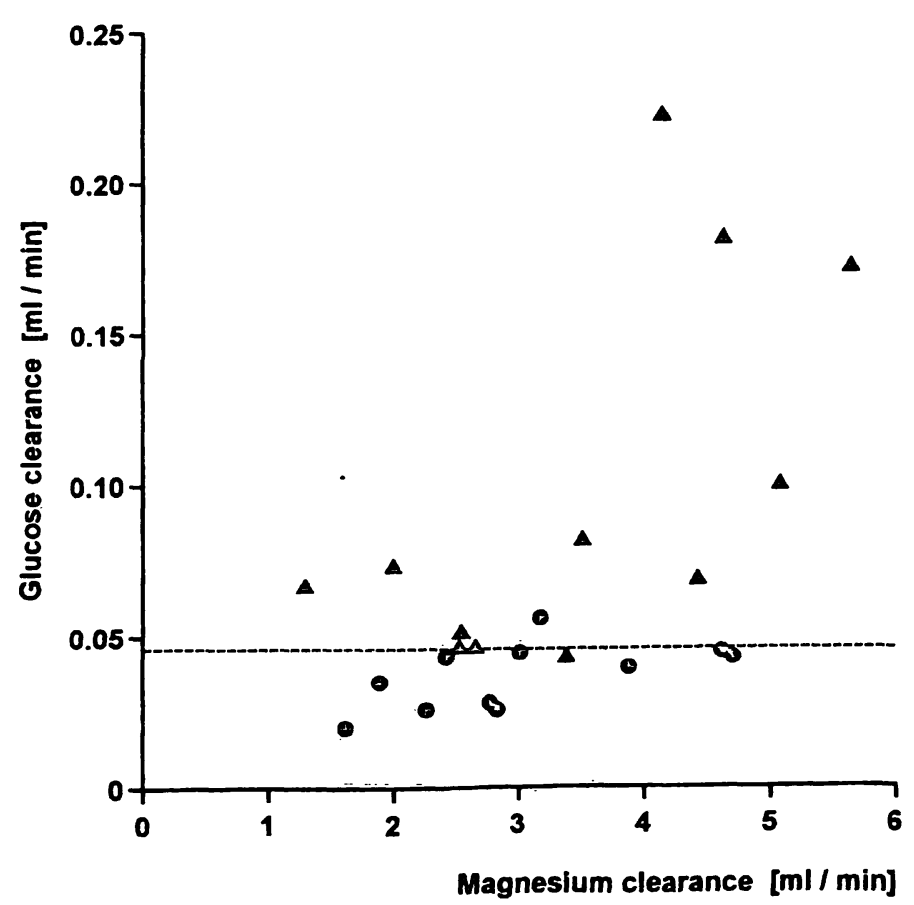

Fig. 1 Interrelationship of the clearances of total magnesium and glucose in fasting urine of male recurrent calcium urolithiasis patients $(\Delta ; n=12)$ and healthy controls $(0 ; n=11)$. The dashed line denotes that in the majority of recurrent calcium urolithiasis subjects glucosuria is $>0.046 \mathrm{ml} / \mathrm{min}$. For further details see text. asis was 4.4 per cent less than in controls, there were no statistically significant differences detectable in serum or plasma.

In fasting urine of recurrent calcium urolithiasis patients, the $\mathrm{pH}$ was significantly elevated, as were protein and glucose; the creatinine clearance, albumin, sodium, and potassium all tended to show higher, phosphate and $\mathrm{Mg}$ lower values than in controls. The degree of proteinuria and albuminuria was not different between recurrent calcium urolithiasis patients with stones in situ and those without stones at the time of examination. There was a significant positive correlation between the urinary clearances of $\mathrm{Mg}$ and glucose $(r=0.56, p<0.01)$, with a steeper slope of the regression line for the patients ( $\mathrm{n}=12, \mathrm{r}=0.62$, slope $=0.03$ ) than for the controls $(\mathrm{n}=11, \mathrm{r}=0.575$, slope $=0.006$ ) (fig. 1). Applying a cut-off point of $0.046 \mathrm{ml} / \mathrm{min}$ glucose clearance to the plot largely separates the two groups, only a single individual being definitively common to both. No other correlations with urinary glucose as the dependent variable could be detected.

$\mathrm{Mg}$ in erythrocytes, biological $\mathrm{Mg}$ fractions (tab. 2)

$\mathrm{Mg}$ in erythrocytes of recurrent calcium urolithiasis patients was about $9.5 \%$ lower than in controls, with the difference being very close to the level of significance (for reference values see 1.c. $(24,25)$ ). Also in recurrent calcium urolithiasis, the serum total and protein-bound $\mathrm{Mg}$ concentrations were about 7 and $13 \%$ lower ( $p<0.05$, and of borderline significance, respectively), and the mean values of ultrafilterable and ionised $\mathrm{Mg}$ 
Tab. 2 Magnesium $(\mathrm{Mg})$ in red blood cells and $\mathrm{Mg}$ fractions in scrum, all in $\mathrm{mmol} / \mathrm{l}$, of stone patients and healthy subjects (con- trols). Mean values (SEM). For further details see text. *: $p \leq 0.05$ vs controls.

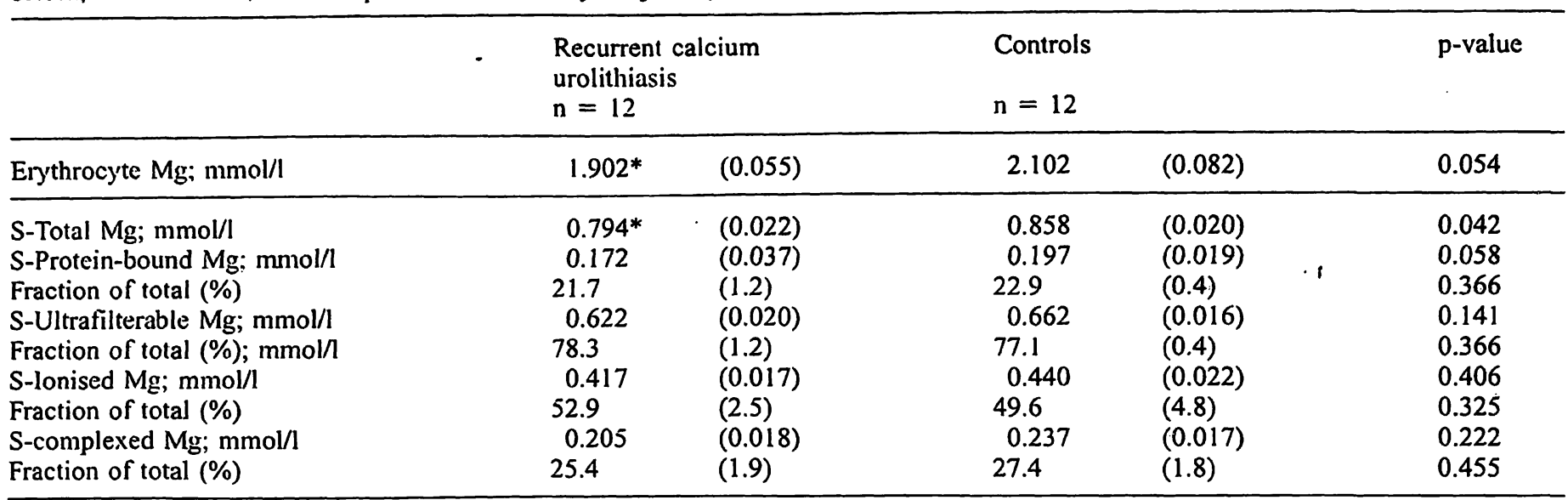

were each about $5 \%$ lower than in controls. In both recurrent calcium urolithiasis and controls the proteinbound and ultrafilterable $\mathrm{Mg}$ concentrations as a percentage of total serum $\mathrm{Mg}$ were similar to those reported for healthy individuals (25). There was no significant correlation between erythrocyte $\mathrm{Mg}$ and serum total $\mathrm{Mg}$ (recurrent calcium urolithiasis, $\mathrm{n}=12, \mathrm{r}=0.092$, $\mathrm{p}=0.789$; controls, $\mathrm{n}=12, \mathrm{r}=0.296, \mathrm{p}=0.351$ ) or ultrafilterable $\mathrm{Mg}$ (recurrent calcium urolithiasis, $\mathrm{n}=12, \mathrm{r}=0.140, \mathrm{p}=0.681 ; \quad$ controls, $\mathrm{n}=12$, $r=0.331, p=0.294)$.

Urinary $\mathrm{Mg}$, protein and glucose at comparable creatinine clearance in recurrent calcium urolithiasis and controls (tab. 3)

To rule out the possibility that differences in the filtered load of $\mathrm{Mg}$ interfere with the amount of $\mathrm{Mg}$ in the final urine, we selected eight individuals from each of the twelve recurrent calcium urolithiasis patients and controls, who had almost identical creatinine clearance. This resulted in practically the same values for the Mg excretion rate and urinary $\mathrm{Mg} /$ creatinine ratio in recurrent

Tab. 3 Renal handling of magnesium (Mg) in 8 recurrent calcium urolithiasis patients and controls, respectively, with comparable mean creatinine clearance (as a marker of glomerular filtration calcium urolithiasis and controls; also with all other $\mathrm{Mg}$ variables studied significant difference between the groups. However, in recurrent calcium urolithiasis, the excretion rate of free $\mathrm{Mg}$ ions was slighly higher, and that of complexed $\mathrm{Mg}$ slightly lower than in controls; in addition, the mean fractional clearance of total and ionised $\mathrm{Mg}$ in these eight recurrent calcium urolithiasis patients was also higher, indicating the presence of some factor able to influence net tubular reabsorption of $\mathrm{Mg}$. Urinary protein was 3.3-fold higher, and urinary glucose 2.8-fold higher in recurrent calcium urolithiasis patients than in controls.

\section{State of supersaturation of urine (tab. 4)}

In recurrent calcium urolithiasis as a whole group (12 patients) the mean relative supersaturation products of calcium oxalate was apparently lower than in controls (12 subjects), the difference being of borderline significance. In contrast, the mean relative supersaturation products of hydroxyapatite in recurrent calcium urolithiasis was 1.8- to 2-fold higher than in controls, due mainly to their higher urinary $\mathrm{pH}$ (see table 1), whereas rate). Mean values (range). Fractional excretion is synonymous with fractional clearance. For other abbreviations and details see table 1 and text. ${ }^{*}: \mathrm{p}<0.05$ vs Controls.

$\begin{array}{lll}\begin{array}{l}\text { Recurrent calcium } \\ \text { urolithiasis }\end{array} & \text { Controls } & \text { p-value } \\ \mathrm{n}=8 & \mathrm{n}=8 & \end{array}$

\begin{tabular}{|c|c|c|c|c|c|}
\hline Creatinine clearance; $\mathrm{ml} / \mathrm{min}$ & 119 & $(91-154)$ & 119 & $(86-168)$ & 0.943 \\
\hline U-Protein; $\mathrm{g} / \mathrm{mol}$ creatinine & $6.36^{*}$ & $(0.98-21.3)$ & 1.91 & $(0.68-3.72)$ & 0.041 \\
\hline U-Glucose; $\mathrm{mol} / \mathrm{mol}$ creatinine & $0.054 *$ & $(0.02-0.13)$ & 0.019 & $(0.01-0.036)$ & 0.003 \\
\hline $\mathrm{Mg} ; \mathrm{mol} / \mathrm{mol}$ creatinine & 0.24 & $(0.08-0.45)$ & 0.23 & $(0.14-0.40)$ & 0.713 \\
\hline Filtered load of ionised $\mathrm{Mg} ; \mu \mathrm{mol} / \mathrm{min}$ & 51 & $(41-66)$ & 52 & $(30-71)$ & 0.832 \\
\hline Filtered load of complexed $\mathrm{Mg} ; \mu \mathrm{mol} / \mathrm{min}$ & 25 & $(7-42)$ & 29 & $(21-42)$ & 0.478 \\
\hline Filtered load of total $\mathrm{Mg} ; \mu \mathrm{mol} / \mathrm{min}$ & 75 & $(49-98)$ & 80 & $(55-96)$ & 0.523 \\
\hline Ionised $\mathrm{Mg}$ excretion; $\mu \mathrm{mol} / \mathrm{min}$ & 1.5 & $(0.5-2.7)$ & 1.3 & $(0.7-2.0)$ & 0.713 \\
\hline Complexed $\mathrm{Mg}$ excretion; $\mu \mathrm{mol} / \mathrm{min}$ & 1.0 & $(0.3-1.7)$ & 1.2 & $(0.6-1.8)$ & 0.431 \\
\hline $\mathrm{Mg}$ excretion; $\mu \mathrm{mol} / \mathrm{min}$ & 2.5 & $(0.9-4.3)$ & 1.5 & $(1.6-3.4)$ & 0.958 \\
\hline Fractional excretion of ionised $\mathrm{Mg} ; \%$ & 3.0 & $(0.8-5.4)$ & 2.5 & $(1.4-2.9)$ & 0.603 \\
\hline Fractional excretion of complexed $\mathrm{Mg} ; \%$ & 4.0 & $(1.6-7.4)$ & 4.2 & $(2.7-7.5)$ & 0.846 \\
\hline Fractional excretion of total $\mathrm{Mg}, \%$ & 3.2 & $(1.0-5.0)$ & 2.9 & $(1.9-3.8)$ & 0.954 \\
\hline
\end{tabular}


Tab. 4 Relative supersaturation products for calcium oxalate, brushite, and hydroxyapatite in recurrent calcium urolithiasis patients and controls, respectively. Mean values (range).

\begin{tabular}{|c|c|c|c|c|}
\hline Relative supersaturation products of & $\mathbf{n}$ & $\begin{array}{l}\text { Recurrent calcium } \\
\text { urolithiasis }\end{array}$ & Controls & $\mathrm{p}$-value \\
\hline $\begin{array}{l}\text { Calcium oxalate; } \Delta G^{*} \\
\text { Hydroxyapatite; } \Delta G \\
\text { Brushite; } \Delta G\end{array}$ & $\begin{array}{l}12 \\
12 \\
12\end{array}$ & $\begin{array}{r}1.5 \\
3.3 \\
-1.0\end{array}$ & $\begin{aligned} 2.2 & (1.0-3.3) \\
1.8 & (-1.6-5.1) \\
-0.9 & (-3.5-0.5)\end{aligned}$ & $\begin{array}{l}0.083 \\
0.133 \\
0.977\end{array}$ \\
\hline
\end{tabular}

*: free energy (see 1. c. (22))

the mean relative supersaturation product of brushite was comparable in recurrent calcium urolithiasis and controls.

\section{Discussion}

Current understanding of $\mathrm{Mg}$ status in recurrent calcium urolithiasis

We assessed the $\mathrm{Mg}$ status in male recurrent calcium urolithiasis patients, strictly matched with controls for age, weight, and body mass, and we included in the examination erythrocyte $\mathrm{Mg}$, serum total $\mathrm{Mg}$ and its protein-bound, ultrafilterable, ionised, and complexed fractions, as well as ionic and complexed urinary $\mathrm{Mg}$. Erythrocyte $\mathrm{Mg}$ was examined because $\mathrm{Mg}$ concentration in these cells is genetically controlled (26), and therefore is largely independent of intestinal $\mathrm{Mg}$ uptake and acute changes in extracellular $\mathrm{Mg}$ (see below). Furthermore, the $\mathrm{Mg}$ content of nuclei-containing skeletal muscle cells did not differ between renal stone patients and healthy controls (12). Thus, in the synopsis our data probably correctly reflect the $\mathrm{Mg}$ status during the chosen time segment of a daily cycle, viz., 2 hours in the morning, after a prior 12-15 hours nocturnal fast.

The frequency of recurrent calcium urolithiasis is greatest in the fourth and fifth decade of life (27), with a maximum around the age of 40 years. Our data on $\mathrm{Mg}$ demonstrate that even younger recurrent calcium urolithiasis patients exhibit signs of an impaired $\mathrm{Mg}$ status. This situation may have escaped detection by previous investigators, because age was not conceived as a possibly biasing factor $(12,13)$. Thus, in our laboratory, male normocalciuric patients older than 40 revealed similar tubular handling of $\mathrm{Mg}$, yet there was no evidence of $\mathrm{Mg}$ deficiency in erythrocytes or serum (unpublished data); independency of blood cell and total serum $\mathrm{Mg}$ from age was also found for healthy humans (28). However, intestinal transport of $\mathrm{Mg}$ decreases with age, but is maintained at near normal levels at the expense of regulatory hyperparathyroidism (29), thereby masking the presence of a generalised abnormal $\mathrm{Mg}$ status.

Another reason for the discrepant data on the state of $\mathrm{Mg}$, especially magnesiuria, in the literature (for review see 1. c. (14)), may be sought in the degree of the associated calciuria. Thus, many hypercalciuric stone patients, who show a filtered load of $\mathrm{Mg}$ similar to that of normocalciuric stone patients, are unable to increase $\mathrm{Mg}$ reabsorption appropriately; consequently they excrete even more $\mathrm{Mg}$ than controls (unpublished data). Similar findings were reported by others who examined $\mathrm{Mg}$ in $4 \mathrm{~h}$ fasting urine and $24 \mathrm{~h}$ urine of renal calcium stone patients $(30-33)$. In the present work three recurrent calcium urolithiasis patients were classified as having idiopathic hypercalciuria (see Materials and Methods); they were not omitted but instead further studied although all $\mathrm{Mg}$ values were at the upper limit of the range observed for the normocalciuric patients.

\section{Magnesium in blood}

In the literature the values of erythrocyte $\mathrm{Mg}$ in healthy controls are generally higher, probably due to the use of different methodology $(22,24)$. Erythrocyte $\mathrm{Mg}$ is determined during maturation of the erythrocytes in bone marrow (34). There are conflicting reports regarding the mobility of $\mathrm{Mg}$ in erythrocytes. While $\mathrm{Mg}$ in blood cells in general was found to represent a more mobile pool, in contrast to parenchymatous organs like the liver and probably the kidney (35), a recent report states that in human erythrocytes the transmembrane $\mathrm{Mg}$ fluxes are slowed (36).

Consistent with the latter view would be the absence of a correlation between erythrocyte $\mathrm{Mg}$ and serum or ultrafilterable $\mathrm{Mg}$ in both recurrent calcium urolithiasis and controls (see Results). Therefore, the decrease of erythrocyte $\mathrm{Mg}$ in recurrent calcium urolithiasis as a whole group may be due to a long-term $\mathrm{Mg}$ deficiency of the whole body, probably resulting from an inadequate supply of exogenous $\mathrm{Mg}$ rather than enhanced $\mathrm{Mg}$ losses (see also below). Mg depletion of food in Western civilisation is supected of being one cause of low serum total $\mathrm{Mg}$ (37), and our findings of low serum total and protein-bound $\mathrm{Mg}$ in recurrent calcium urolithiasis would be compatible with this view. Alternatively, low serum total $\mathrm{Mg}$ as a consequence of impaired intestinal $\mathrm{Mg}$ uptake in recurrent calcium urolithiasis deserves consideration, but its occurrence in the relatively young individuals studied by us is unlikely. It should be noted that although the protein-bound fraction of serum $\mathrm{Mg}$ is reduced in proportion to the low serum albumin (see tab. 1), it is not alone responsible for the low total $\mathrm{Mg}$; to a 
certain extent all serum fractions contribute to the deficit of total $\mathrm{Mg}$ (tab. 2). This situation is similar to that reported by others, in that changes of serum albumin within the normal limits did not account for changes of serum total $\mathrm{Mg}(38)$.

In controls, the mean value of ionised $\mathrm{Mg}$ was about 20 per cent lower than that reported by Altura and coworkers (25), although in the laboratory of these workers and our own the same Mg sensitive electrode was used. The reason for this discrepancy is not readily recognizable. However, the subjects studied by these workers were on average older [29 years (present work) vs 59, (25)] and their blood $\mathrm{pH}$ was an average higher [7.392 (present work) vs 7.465 (25)], suggesting that either an age-related increase of free ions in plasma, decreased complexation or protein-binding of ions, or some combination of these two effects was responsible (see below). As these authors (25) provided no further information on serum total protein, albumin, and citrate, the true state of ionised $\mathrm{Mg}$, an important biological property, remains unclear. Free ionised $\mathrm{Mg}$ in plasma results from the balance of $\mathrm{Mg}$ bound to macromolecules and complexed by small molecules, such as citrate or fatty acids. In our recurrent calcium urolithiasis patients, albumin was low (tab. 1) and citrate was indistinguishable from controls (see Material and Methods), so that ionised $\mathrm{Mg}$ in recurrent calcium urolithiasis should not have been low thereby contrasting with the values reported by other authors (25) - but should have remained normal or even high. Thus, from the available data, the factor underlying the mean lower concentration of serum ionised $\mathrm{Mg}$ in recurrent calcium urolithiasis is not discernable, but may in part reflect the mean higher $\mathrm{Mg}$ ion exretion via urine (see below, and tab. 3).

\section{Renal function and $\mathrm{Mg}$ in recurrent calcium urolithiasis}

Recurrent calcium urolithiasis patients exhibited a number of abnormalities so far not generally recognised (tab. 1; fig. 1). In fasting urine these abnormalities include hyperproteinuria, hyperglucosuria, less acidic $\mathrm{pH}$, and a trend toward higher creatinine clearance and higher albuminuria. Hyperproteinuria and hyperglucosuria persist after correction for creatinine clearance (see tab. 3). These findings support the contention that some abnormality of the nephron, be it functional, morphological, or both, is present in recurrent calcium urolithiasis. In searching for the origin of these, a somewhat disordered $\mathrm{Mg}$, or some other disorder not studied here, may be considered as the critical factor(s).

Dietary $\mathrm{Mg}$ deficit is discussed as causing abnormalities in blood lipids in the rat (39), and disturbances of lipids are a constant feature of kidney diseases in humans, especially glomerular lesions (40). Thus, lipid-induced but
Mg-dependent injury of both glomeruli and tubules might exist in the recurrent calcium urolithiasis patients in the present work, and may have facilitated the appearance in urine of proteins, whose access to the tubular lumen is normally prevented by intact tissues. On the other hand, the composition and metabolism of lipids may be primarily altered in recurrent calcium urolithiasis (41); also alteration of lipids has been discussed as one possible cause of increased $\mathrm{Mg}$ retention, which itself reflects the body's need to conserve $\mathrm{Mg}$ (42). Work related to such possibilities is currently in progress in our laboratory.

With the technical tools presently available it is not feasible to probe in situ, i. e. inside renal tubular cells, the state of $\mathrm{Mg}$, to determine the cytosolic free $\mathrm{Mg}$ ion concentration or the concentration of $\mathrm{Mg}$ bound to subcellular structures. If low erythrocyte $\mathrm{Mg}$ reflects low renal cell $\mathrm{Mg}$, regardless of the aetiology of $\mathrm{Mg}$ deficit, then events adversely affecting intracellular processes may be the consequence. Cellular $\mathrm{Mg}$ deficiency would lead to impaired phosphorylation due to the uncoupling of $\mathrm{Mg}$ substrate binding, thereby preventing the reaction of the complex with hexokinase $(43,44)$, the key enzyme in transmembrane flux of (phosphorylated) glucose. Thus, in our recurrent calcium urolithiasis patients without overt signs of diabetes and insulin deficiency, the increased glucosuria should arise from decreased glucose uptake by the luminal structures of proximal tubular cells. Moreover, inappropriately high phosphaturia, as was found in $\mathrm{Mg}$-deficient rats devoid of parathyroid glands (45), should also occur in recurrent calcium urolithiasis with normal parathyroid gland function; in the long-term such a situation should lead to some degree of phosphate deficiency. In fact, the latter may be recognised in both the low phosphate of fasting serum (46) and low urinary phosphate $(46,47$; this work); both of these phenomena are lesser known features of recurrent calcium urolithiasis, as is exaggerated phosphaturia in response to a carbohydrate- and calcium-rich test meal, i. e. during a postprandial period with calcium-induced suppression of the phosphaturic component of parathyroid hormone (48).

$\mathrm{Mg}$ deficiency causes increased oxidative stress to various tissues, reflected in an increased lipid peroxidation $(49,50)$. One of the manifestations of oxidative stress is injury to endothelial cells (49) and, if $\mathrm{Mg}$ deficiency is severe, loss of the integrity of unspecified renal cell membranes (50). The steep blood-lumen $\mathrm{pH}$ gradient normally achieved by proton secretion into the distal tubule is linked to the activity of a $\mathrm{Mg}^{2+}$ ATPase of the luminal membrane (51). Thus, impaired acidification of fasting urine in $\mathrm{Mg}$-deficient males with recurrent calcium urolithiasis (table 1), already previously described by us (52), may reflect an inadequate enzyme activity due to renal tubular cell damage, hence dimin- 
ished proton generation. Viewed together, these interrelationships appear to show that $\mathrm{Mg}$ deficit is a potential common denominator of several abnormalities seen in recurrent calcium urolithiasis.

\section{Calcifications and $\mathrm{Mg}$}

In pre-lithotripsy patients we found that the surface of stones in situ is smaller in the presence of high urinary $\mathrm{Mg}$ ion concentration, and vice versa (53); however, these patients were older, and obesity and calciuria were not strictly controlled. In the present work, a role of $\mathrm{Mg}$ in the aetiology of crystals or stones remains uncertain, considering the unaltered $\mathrm{Mg}$ in urine (tab. 3), and the associated supersaturation products of calcium oxalate and brushite (tab. 4). However, the higher protein and the trend to higher albumin in urine of recurrent calcium urolithiasis may lend research interests into promising

\section{References}

1. Wallach S. Relation of magnesium to osteoporosis and calcium urolithiasis. Magnes Trace Elem 1991-2; 10:281-6.

2. Bigi A, Foresti E, Gregorini R, Ripamonti A, Roveri N, Shah JS. The role of magnesium in the structure of biological apatites. Calcif Tissue Int 1992; 50:439-44.

3. Finlayson B. Calcium stones: some physical and clinical aspects. In: David DS, editor. Calcium metabolism in renal failure and nephrolithiasis. New York, London, Sidney, Toronto: Wiley, 1977:337-82.

4. Hallson PC, Rose GA, Sulaiman S. Magnesium reduces calcium oxalate crystal formation in human whole urine. Clin Sci 1982; 62:17-9.

5. Kohri K, Garside J, Blacklock NJ. The role of magnesium in calcium oxalate urolithiasis. Br J Urol 1988; 61:107-15.

6. Wilson JWL, Werness PG, Smith LH. Inhibitors of crystal growth of hydroxyapatite: a constant composition approach. J Urol 1985; 134:1255-8.

7. Rattan V. Biochemical studies on calcium and oxalate metabolism in magnesium deficient rats with special reference to urolithiasis [dissertation]. Chandigarh (India): Panjab University, 1992.

8. Rattan V, Thind SK, Jethi RK, Sidhu H, Nath R. Oxalate metabolism in magnesium-deficient rats. Magnes Res 1993; $6: 127-33$.

9. Hammarsten G. On calcium oxalate and its solubility in the presence of inorganic salts with special reference to the recurrence of oxaluria. CRC Lab Carlsberg 1929; 17:1-85.

10. Desmars JF, Tawashi R. Dissolution and growth of calcium oxalate monohydrate. I. Effect of magnesium of $\mathrm{pH}$. Biochim Biophys Acta 1973; 313:256-67.

11. Schwille PO, Schlenk I, Samberger NM, Bornhof C. Fasting urine excretion of magnesium, calcium, and sodium on patients with renal calcium stones. Urol Res 1976; 4:33-43.

12. Johannson $G$, Backman $U$, Danielson $B G$, Ljunghall $S$, Wikström B. Magnesium metabolism in renal stone disease. Invest Urol 1980; 18:93-6.

13. Resnick MI, Munday D, Boyce WH. Magnesium excretion and calcium oxalate urolithiasis. Urology 1985; 20:385-9.

14. Ryall RL, Marshall VR. The investigations and management of idiopathic urolithiasis. In: Wickham JEA, Buck AC, editors. Renal tract stone. Edinburgh, London, Melbourne, New York: Churchill Livingstone, 1990:307-31.

15. Ljunghall $S$, Hedstrand $H$. Glucose metabolism in renal stone formers. Urol Int 1978; 33:417-21.

16. Speich M, Gelot S, Amaud P, Van Goc N, Robinet N, Pineau A. Multiple and simple correlations between magnesium, calcium, zinc, potassium, total and HDL-cholesterol in 111 reference subjects. Magnesium Bull 1984; 4:137-41. directions. Although the degree of hyperproteinuria is small, the finding is reminiscent of preclinical signs in human individuals at risk of developing atherosclerosis (see 1.c. (53)) and non-insulin-dependent diabetes mellitus, the latter being frequently associated with a cellular $\mathrm{Mg}$ deficit (55). Several proteins bind calcium; hence, even a small excess of proteins and possibly albumin, which is a constituent of stone matrix (56), may help to glue crystals together. The diameter of such crystallised particles, not single crystals, determines whether obstruction of the tubular lumen and formation of microliths occur (57).

\section{Acknowledgements}

We are grateful to G. Hoffmann and B. Schreiber for technical assistance, and $I$. Goldberg for secretarial work.

17. Scholz D, Schwille PO. Klinische Laboratoriumsdiagnostik der Urolithiasis. Dtsch Med Wochenschr 1981; 106:9991002.

18. Irving RA, Noakes TD, Rodgers AL, Swartz L. Crystalluria in Marathon runners. Urol Res 1986; 14:289-94.

19. Schwille $P O$, Manoharan $M$, Rümenapf $G$, Wölfel $G$, Berens $\mathrm{H}$. Oxalate measurement in the picomol range by ion chromatography: values in fasting plasma and urine of controls and patients with idiopathic calcium urolithiasis. J Clin Chem Clin Biochem 1989; 27:87-96.

20. Altura BT, Shirey TL, Young CC, Hiti J, Dell'Orfano K, Handwerker SM, et al. A new method for the rapid determination of ionized $\mathrm{Mg}^{2+}$ in whole blood, serum and plasma. Meth Find Exp Clin Pharmacol 1992; 14:297-304.

21. Moellering H, Gruber W. Determination of citrate with citrate lyase. Anal Biochem 1966; 17:369-76.

22. Abraham GE, Lubran MM. Serum and red cell magnesium levels in patients with premenstrual tension. Am J Clin Nutr $1981 ; 34: 2364-6$.

23. Werness PG, Brown CM, Smith LH. EQUIL 2: a BASIC computer program for the calculation of urinary saturation. $J$ Urol $1985 ; 134: 1242-4$.

24. Alfrey AC, Miller NL, Butkus D. Evaluation of body magnesium stores. J Lab Clin Med 1974; 84:153-62.

25. Altura BT, Altura BM. A method for distinguishing ionized, complexed and protein-bound $\mathrm{Mg}$ in normal and diseased subjects. Scand J Clin Lab Invest 1994; 54 Suppl 217:83-7.

26. Darlu P, Rao DC, Henrotte JG, Lalouel JM. Genetic regulation of plasma and red blood cell magnesium concentrations in man. I. Univariant and bivariant path analyses. Am J Hum Genet 1982; 34:874-87.

27. Schwille PO, Scholz D, Sigel A. Urolithiasis - ein Überblick zur Pathophysiologie, Diagnostik und Therapie. Wien Klin Wochenschr 1980; 92:411-20.

28. Yang XY, Hosseini JM, Ruddel ME, Elin RJ. Blood magnesium parameters do not differ with age. J Am Coll Nutr 1990; 9:308-13.

29. Endres DB, Morgan CH, Garry PJ, Ohmdahl JL. Age related changes in serum immunoreactive parathyroid hormone and its biological action in healthy men and women. J Clin Endocrinol Metab 1987; 65:724-31.

30. Evans R, Forbes M, Sutton R, Watson L. Urinary excretion of calcium and magnesium in patients with calcium containing renal stones. Lancet 1967; ii:958-61.

31. Sutton RAL. Renal handling of calcium and magnesium in idiopathic stone disease. Contr Nephrol 1987; 58:93-100.

32. Cetina N, Duvancic S, Tucak A, Kozmar D, Dekanic D. Magnesium excretion in normocalcaemic kidney stone formers. In: 
Vahlensieck W, Gasser G, Hesse A, Schoeneich G, editors. Urolithiasis. Amsterdam, Hong Kong, Princeton, Sydney, Tokyo: Excerpta Medica 1990:32-4.

33. Martinez ME, Salinas M, Miguel JL, Herrero E, Gomez P, Garcia J, et al. Magnesium excretion in idiopathic hypercalciuria. Nephron 1985; 40:446-50.

34. Elin RJ, Assessment of magnesium status. Clin Chem 1987; 33:1965-70.

35. Brilla L, Frederickson IH, Lombardi VP. Effect of hypomagnesemia and exercise on slowly exchanging pools of magnesium. Metabolism 1989; 38:797-800.

36. Schatzmann HJ. Asymmetry of the magnesium sodium exchange across the human red cell membrane. Biochim Biophys Acta 1993; 1148:15-8.

37. Marier JR. Dietary magnesium and drinking water: effects on human health status. In: Sigel H, Sigel A, editors. Metal ions in biological systems. New York, Basel: Marcel Dekker, 1990:85-104.

38. Kroll MH, Elin RJ. Relationship between magnesium and protein concentrations in serum. Clin Chem 1985; 31:244-6.

39. Gueux E, Mazur A, Cardot P, Rayssiguier Y. Magnesium deficiency affects plasma lipoprotein composition in rats. $J$ Nutr $1991 ; 121: 1222-7$.

40. Guijarro C, Keane WF. Lipid abnormalities and changes in plasma proteins in glomerular diseases and chronic renal failure. Curr Opin Nephrol Hypertens 1993; 2:372-9.

41. Varalakshmi G, Radha Shanmuga Sundaram K, Venugopal A. Blood lipids in renal stone disorders. Indian J Med Res 1977; 66:840-6.

42. Nozue T, Kobayashi A, Uemasu F, Takagi Y, Sako A, Endoh H. Magnesium status, serum HDL cholesterol, and apolipoprotein A-1 levels. J Pediatr Gastroenterol Nutr 1995; 20:316-8.

43. Ebel H, Günther T. Magnesium metabolism: a review. J Clin Chem Clin Biochem 1980; 18:257-70.

44. Cohn M. Magnetic resonance studies of metal activation of enzymatic reactions of nucleotides and other phosphate substrates. Biochemistry 1963; 2:623-9.

45. Ginn HE, Shanbour LL. Phosphaturia in magnesium-deficient rats. Am J Physiol 1967; 212:1347-50.

46. Schwille PO, Samberger NH, Wach B. Fasting uric acid and phosphate in urine and plasma of renal calcium-stone formers. Nephron 1976; 16:116-25.

47. Rodgers A, Barbour L, Pougnet B, Lombard C, Ryall R. Urinary element concentrations in kidney stone formers and nor- mal controls: the week-end effect. J Trace Elem Electrol Health Dis $1994 ; 8: 87-91$.

48. Schwille PO, Rümenapf G, Köhler R. Blood levels of glucometabolic hormones and urinary saturation with stone-forming phases after an oral testmeal in male patients with recurrent idiopathic calcium urolithiasis and in healthy controls. J Am Coll Nutr 1989; 8:557-66.

49. Dickens BF, Weglicki WB, Li YS, Mak IT. Magnesium deficiency in vitro enhances free radical-induced intracellular oxidation and cytotoxicity in endotheial cells. FEBS Letters 1992; 311:187-91.

50. Vormann J, Günther T, Höllriegl V, Schumann K. Effect of various degrees and duration of magnesium deficiency on lipid peroxidation and mineral metabolism in rats. Nutrit Biochem 1995; 6:681-8.

51. Kinne-Safran E. Renal $\mathrm{H}^{+}$-ATPases. Ann NY Acad Sci 1989; 574:189-203.

52. Herrmann U, Schwille PO. Crystalluria determined by polarization microscopy. Technique and results in bealthy control subjects and patients with idiopathic recurrent calcium urolithiasis classified in accordance with calciuria. Urol Res 1991; 19:151-8.

53. Schwille PO, Herrmann U. Environmental factors in the pathophysiology of recurrent idiopathic calcium urolithiasis (RCU), with emphasis on nutrition. Urol Res 1992; 20:70-81.

54. Jensen JK, Borch-Johnsen K, Jensen G, Feldt-Rasmussen B. Microalbuminuria reflects a generalized transvascular albumin leakiness in clinically healthy subjects. Clin Sci 1995; 88:629-33.

55. Resnick LM, Altura BT, Gupta RK, Laragh JH, Alderman MH, Altura BM. Intracellular and extracellular magnesium depletion in Type 2 (non-insulin-dependent) diabetes mellitus. Diabetologia 1993; 36:767-70.

56. Dussol B, Geider S, Lilova A, Léonetti F, Dupuy P, Daudon $M$, et al. Analysis of the soluble organic matrix of five morphologically different kidney stones. Evidence for a specific role of albumin in the constitution of the stone protein matrix. Urol Res 1995; 23:45-51.

57. Kok DJ, Khan SR. Calcium oxalate nephrolithiasis, a free or fixed particle disease. Kidney Int 1994; 46:847-54.

Received October 17, 1995/January 26, 1996

Corresponding author: Prof. Dr Paul O. Schwille, University Hospital, Department of Surgery, Maximiliansplatz 2, D-91023 Erlangen, Germany 